\title{
MJN THE EFFECT OF KNEE EXERCISE AND PARAM GINGER TO REDUCE KNEE PAIN IN ELDERLY
}

\author{
Theresia Titin Marlina *, Veronica Ima Pujiastuti \\ School of Health and Science Panti Rapih Yogyakarta, Indonesia \\ *Corresponding Author's Email: titin_marlina@stikespantirapih.ac.id
}

\begin{abstract}
Background: Higher life expectancy in Indonesia contributes to the increasing number of elderly populations. Due to this situation, the dependent burden of productive age to non-productive expanding. Many diseases occur in the elderly, including degenerative joint disease, account for $11.9 \%$ in Indonesia and $6 \%$ occurring in the Special Region of Yogyakarta. Among 34 provinces in Indonesia, Yogyakarta and 4 other provinces were identified to have an old population structure where the proportion of elderly reached 10 percent or above. In 2019, the elderly population in Yogyakarta account for 14.50 percent (Central Bureau of Statistics Indonesia. (2019). Following changes in the population structure in which the number of elderly people is rising and occupied as a province with the highest elderly population rate, arthritis became the second-highest disease incidence in Yogyakarta. Current evidence related to exercise and ginger, did not present any studies that combine both of the intervention methods as researchers aimed to identify scientific evidence of exercise and ginger to reduce knee pain in the elderly. Objective: This study aimed to determine the effect of knee exercise and param ginger to reduce knee pain in the elderly. Methods: This is a quantitative study implementing quasiexperimental research, randomized pretest-posttest control design. The population of this study was elderly originated from Pringwulung Village, Yogyakarta. The purposive sample design was intended to recruit participants with age 55-70 years, experiencing knee pain, have no ginger allergy, and willing to participate. The eligible sample of this study was 40 participants. The intervention was carried out for 4 weeks from September to October 2020. Results: Study identified significant differences in pain levels before and after knee exercise $(p=0.004)$, before and after knee exercise and param ginger $(p=0.004)$, and before and after receiving param ginger $(p=0.006)$. Conclusion: Knee exercise and param ginger provide a significant effect to reduce knee pain in the elderly.
\end{abstract}

Keywords: Knee Exercise; Knee Pain; Param Ginger

\section{INTRODUCTION}

Center for Data and Information of the Ministry of Health Indonesian (Pusdatin Kemenkes), reported that the average life expectancy in Indonesia is slightly higher compared to the world average life expectancy. In 2015 - 2020, life expectancy in Indonesia is 71.7 years, while in the world is 71 years. This indicated that successful development in the health sector has led to increased life expectancy. Higher life expectancy resulting in an increasing dependent burden of productive age for non-productive/ elderly people. The life expectancy of the Indonesia people is 72 years in 2018 (The World Bank, 2021).

In Indonesia, one of the five provinces that has an old population structure where the elderly population has reached 10 percent is the Special Region of Yogyakarta with $14.50 \%$ population in 2019 (Central Bureau of Statistics Indonesia., 2019).

In 2018, the country reported decreasing prevalence of the joint disease to $7.3 \%$ but in Yogyakarta, the prevalence is increased to 6\% (Riskesdas 2018). This phenomenon occurred because the Special Region of Yogyakarta is a province with the highest population of elderly people. Based on Government Regulation No. 43 the year 2004 on the Effort Implementation to Improve the Welfare of Elderly, policy and approach to improve the wellbeing of the elderly are demanded, one of aspect is health quality. Potential efforts to be performed are providing aid for the elderly to be free from knee pain complaints. One of the effective methods to relieve pain 
is by doing knee exercises. This is following the results of research by Marlina (2015), which proved that knee exercises were statistically effective in reducing knee pain with $p=0.004$. The systematic review conducted by Fransen, et al., (2015) states that out of 54 studies there are 12 studies that confirmed that exercise significantly reduces knee pain during 2-6 months evaluation after treatment.

Besides, to manage knee pain through exercises, there was also emerging evidence regarding the use of ginger as a traditional medicine that is easily available. Ginger is an herb that is useful as a health stimulant, pain reliever, and a strong antioxidant that effective to treat inflammation due to the content of gingerol compounds. Rondanelli, et al., (2020) reviewed the use of ginger on osteoarthritis pain, low back pain, and migraine. The study concluded that the use of ginger for pain control is promising and more research is necessary to calculate the effective dosage of ginger. Morv Aridzadeh, et al., (2020) completed a systematic review and meta-analysis of the effects of ginger for inflammatory markers and concluded that ginger had a significant impact in reducing circulating levels of CRP (Carbon Reactan Protein), hs-CRP (High-Sensitivity C-Reactan Protein), and TNF- $\alpha$ (Tumor Necrosis Faktor Alpha) which confirm the substantial-benefit to reduce pain. Likewise, the results of the analysis conducted by Bartels et al., (2015) on 5 studies among 593 participants verified that ginger was effective in reducing osteoarthritis pain.

Due to the current situation in which the population of elderly is increasing and arthritis is the second-highest rank disease incidence experienced by elderly in the province, limited research on exercise and ginger, and the lack of combination of both method, researchers aimed to explore scientific findings regarding exercise and ginger this is to reduce knee pain in the elderly.

\section{Aim of Study}

This study aimed to identify the effect of knee exercise and param ginger to reduce knee pain in the elderly.

Hypothesis: knee exercises and param ginger reduces knee pain.

\section{METHODOLOGY}

This is a quantitative study with quasi-experimental research, randomized pretest-posttest control design.
The study design is illustrated in Figure 1.

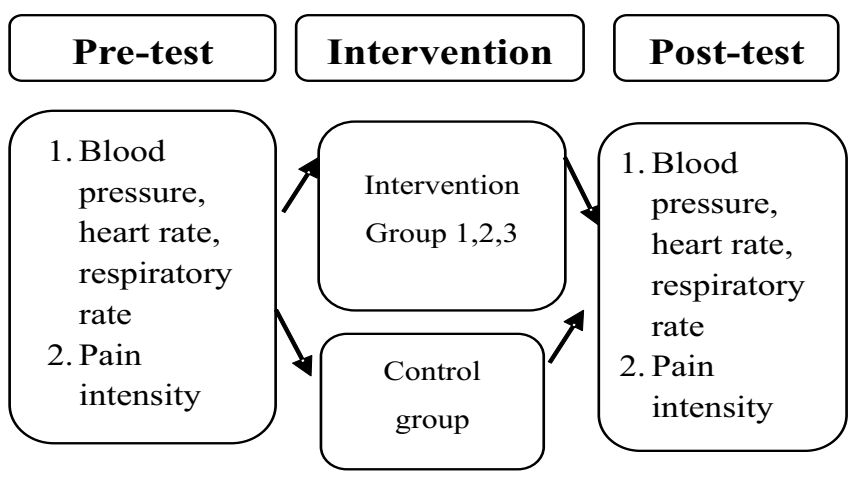

\section{Figure 1: Pre-Test and Post-Test Research Designs}

Before the intervention, all group were measured for blood pressure, height, weight, pulse, respiration, and pain intensity. An then devided into four groups.

Intervention group 1: respondents were given knee extension-flexion exercises for 30 minutes, twice a week, for one month.

Intervention group 2: respondents were given knee extension-flexion exercises for 30 minutes, after which they immediately received 3 grams of param ginger for 1 hour, twice a week, for one month.

Intervention group 3: respondents were given 3 grams of param ginger for 1 hour, twice a week, for one month.

Control group (group 4): respondents were given health education on knee pain management.

After the intervention, all group were measured for blood pressure, height, weight, pulse, respiration, and pain intensity. Assesment pain intensity with numerical pain rating scale $0-10$.

\section{Inclusion and Exclusion Criteria}

The inclusion criteria were the elderly age group 5570 years, have no ginger allergy, reporting complaints of knee pain, and willing to participate in the study. Elderly diagnosed with knee exercise contra-indications were excluded from this study.

\section{Study Samples}

A sample of 40 people taken by purposive sampling, with inclusion and exclusion criteria. They were divided into four groups randomly, with each group of 10 people.

\section{Ethical Consideration}

The ethical clearance of this study was obtained from 
the Health Research Ethics Commission of the Faculty of Health Sciences, Respati University Yogyakarta No. 085.3 / FIKES / PL / III / 2020.

\section{Research Instrument}

The data collection instrument was a checklist sheet for blood pressure, height, weight, pulse, respiration before and after intervention. The pain scale measure used a numerical pain rating scala (NPRS) with scala 0 10 , by classification 0 : no pain, 1-3: mild pain, 4-6: moderate pain, 7-9: severe pain, 10: unbearable pain.

\section{RESULTS}

\section{Respondent characteristics}

Table 1: Respondents Characteristics of by Age, Gender and Pain Scale

\begin{tabular}{|c|c|c|c|c|}
\hline \multirow[b]{2}{*}{ Characteristics } & \multicolumn{3}{|c|}{$\begin{array}{l}\text { Intervention } \\
\end{array}$} & \multirow[b]{2}{*}{$\begin{array}{c}\text { Control } \\
(\%)\end{array}$} \\
\hline & $\begin{array}{c}\text { Param } \\
\text { Ginger }(\%)\end{array}$ & $\begin{array}{c}\text { Knee Exercise } \\
(\%)\end{array}$ & $\begin{array}{r}\text { Knee Exercise \& } \\
\text { Param Ginger (\%) }\end{array}$ & \\
\hline $\begin{array}{l}\text { Number of } \\
\text { Respondents }\end{array}$ & $10(100)$ & $10(100)$ & $10(100)$ & $10(100)$ \\
\hline $\begin{array}{l}\text { Gender: } \\
\text { - Male } \\
\text { - Female }\end{array}$ & $\begin{array}{l}3(30) \\
7(70)\end{array}$ & $\begin{array}{l}3(30) \\
7(70) \\
\end{array}$ & $\begin{array}{l}1(10) \\
9(90)\end{array}$ & $\begin{array}{l}2(20) \\
8(80)\end{array}$ \\
\hline $\begin{array}{l}\text { Age: } \\
-55 \text { - } 60 \text { years } \\
-60 \text { - } 65 \text { years } \\
-66 \text { - } 70 \text { years } \\
\end{array}$ & $\begin{array}{l}2(20) \\
7(70) \\
1(10) \\
\end{array}$ & $\begin{array}{l}8(80) \\
1(10) \\
1(10) \\
\end{array}$ & $\begin{array}{l}1(10) \\
4(40) \\
5(50) \\
\end{array}$ & $\begin{array}{l}4(40) \\
2(20) \\
5(50) \\
\end{array}$ \\
\hline \begin{tabular}{ll}
\multicolumn{2}{l}{ Weight: } \\
$-\quad 40-45 \mathrm{~kg}$ \\
$-\quad 46-50 \mathrm{~kg}$ \\
$-\quad 51-55 \mathrm{~kg}$ \\
$-\quad 56-60 \mathrm{~kg}$ \\
$-\quad>60 \mathrm{~kg}$
\end{tabular} & $\begin{array}{l}2(20) \\
3(30) \\
2(20) \\
2(20) \\
1(10)\end{array}$ & $\begin{array}{l}0(0) \\
0(0) \\
0(0) \\
6(60) \\
4(40)\end{array}$ & $\begin{array}{l}2(20) \\
0(0) \\
0(0) \\
5(50) \\
3(30)\end{array}$ & $\begin{array}{l}1(10) \\
0(0) \\
0(0) \\
6(60) \\
3(30)\end{array}$ \\
\hline
\end{tabular}

Table 1 indicates that the majority of respondents for each group are female (70-90\%). The most respondents in param ginger groups were 60-65 years, in the knee exercise group were 55-60 years, in the knee exercise dan param ginger were 66-70 years and in the control group were 60-70 years. The most respondents have weight over 51 kilograms. Pain Scale Differences before and after knee Exercise.

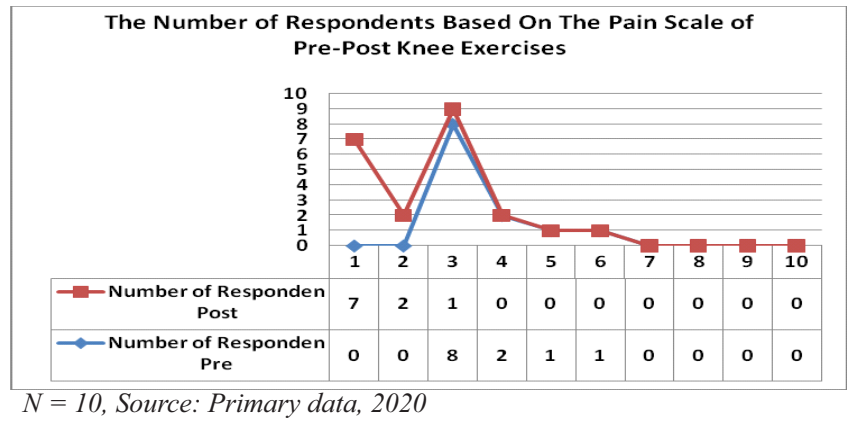

Figure 1: Frequency Distribution of The Number of Respondents Based on Pain Scale Before and After Knee Exercise
Figure 1 indicates a rising number of respondents with pain intensity 1 and 2 as well as a decrease in the number of respondents with pain levels above 3 after the participant knee exercise program. The statistical test yielded $p=0.004$, interpreted as a significant difference in pain level before and after knee exercise. Data analysis using a computer. The data normality test was not normally distributed with Kolmogorov Smirnov 0.00 $(<0.05)$. So the difference test used is non-parametric with the Wilcoxon test.

Differences in Pain Scale Before and After Knee Exercise and Ginger Param

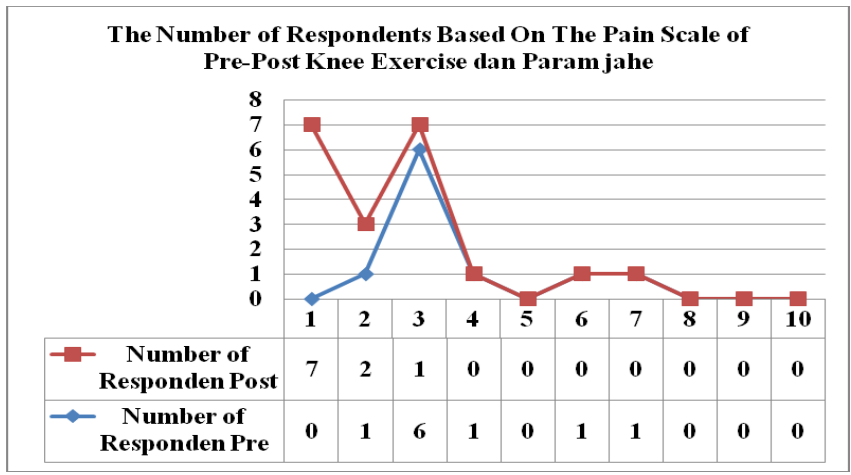

Figure 2: Frequency Distribution of the Number of Respondents based on the Pain scale of Pre-Post Knee Exercise and Param Ginger

Figure 2, there are an increasing number of research participants with pain level 1 and 2 as well as declining reported pain level above 3 after knee exercise and ginger param for 4 weeks intervention. A significant difference between pain before and after knee exercise and param ginger with identified from statistical analysis with $p=0.004$.

The difference in pain scale before and after being given param ginger.

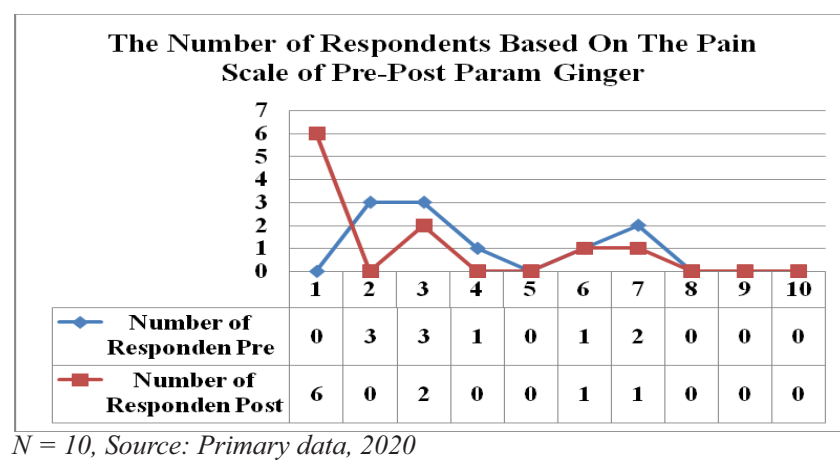

Figure 3: Frequency Distribution of the Number of Respondents Based on the Pain Scale of Pre-Post Param Ginger 
Figure 3 present an increase in the number of respondents with pain level 1 and a decrease in the number of respondents experiencing pain level 7 . Statistical test with the Wilcoxon test resulting significant difference before and after receiving param ginger with $p=0.006(p<0.05)$.

\section{DISCUSSION}

Knee exercises are performed in different positions. The exercise could be done in sitting, standing, or lying down following elderly ability and comfort. A significant statistical difference in pain level was identified before and after knee exercise with $p=0.004$. This is following the results of research by Marlina (2015) and Marlina, et al., (2019) which confirmed that knee exercises were effective to reduce knee pain among patients with knee osteoarthritis. Regular knee exercise promotes blood circulation and metabolism in the patella region. Increasing metabolism in the knee resulting improved joint fluids diffusion which helps the supply of adequate nutrients to the cartilage. Adequate nutrients in the joint cartilage relieve the pain experienced by the elderly and also inhibit joint cartilage breakdown.

Similar results were reported by Firmansyah \& Supayitno (2018). Knee exercises reduce pain in the elderly with osteoarthritis in Kulon Progo, Yogyakarta. A systematic review conducted by Fransen, et al., (2015) reports that among 44 experiments, exercise significantly relieving pain. Pressure on the cartilage as a result of the exercise force water toward out of the matrix into the synovial cavity. At the occurrence of movement, lubricate prevent friction between bones and reduce pain.

Several types of research combine the use of Indonesian traditional medicine including ginger. Ginger (Zingiber officinale Rosc.) is a rhizome plant from the Zingiberaceae family. Currently, ginger is consumed as a spice, beverages, and therapy modality for rheumatism, fever, gastric disorders, bronchitis, diabetes, and cancer (Ali et al., 2018).

Statistically, the study reports a significant difference between pain before and after knee exercise and ginger param with $p=0.004$. Param ginger compressed on the sore knee. This ginger contains zingerone, gingerol, and shagaol which useful to relieve pain. Warmth effects produced by ginger increases the temperature of the skin followed by vasodilation. The vasodilation encourages blood circulation in the surrounding area. Param ginger relief pain in the mechanism of pain transduction. Cyclooxygenase from gingerol substance inhibits prostaglandin as a mediator of pain. Prostaglandins inhibition prevents pain sensation felt by the patient.

Participants' pain level before receiving param ginger were $3.9 \pm 2.025$, while after receiving intervention decreased to an average of $2.5 \pm 2.273$. These results indicate significant difference $p<0.05$ $(p=0.006)$. The pain level evaluation in the elderly is done through numeric pain scale measurement. Significant pain level declining affected by the use of param ginger (Zingiber officinale Rs). Ginger is consumed not only as an herb, but has been known as a traditional medicine. Gingerol and shogaol are active ingredients in ginger that useful as anti-inflammatory substances (Nagendra Chari et al., 2013; Semwal et al., 2015). Gingerol reduces Inducible Nitric Oxide Synthase (iNOs), recognized as a compound that triggers inflammation; reduces TNF- $\alpha$ by inhibiting Ikappa $\mathrm{B}$ alpha phosphorylation, activation of nuclear factor-kappa B (NF-kB), and translocation of protein kinase C-alpha (Lee et al., 2009). Several studies have reported active compound content of gingerol and shogaol reduces inflammation in patients with knee osteoarthritis (Naderi et al., 2016; Rondanelli et al., 2020). Other similar studies conducted by Alipour, et al. (2017) \& Rondanelli, et al., (2020), prove that ginger is effective in reducing pain in knee osteoarthritis patients.

Gingerol is a secondary metabolite compound. The compounds produce a distinctive sharp aroma and taste, usually spicy (Wang et al., 2011). Gingerol able to inhibit the occurrence of joint pain / rheumatoid arthritis in several research took place in vivo, in vitro, as well as in clinical studies in humans (Gunathilake, 2015). 93-97\% of the crude extract of ginger prevents swelling in acute and chronic arthritis (Funk et al., 2009; Ramadan et al., 2011). Morvaridzadeh et al., (2020) conducted a systematic review and metaanalysis which concluded that ginger has a significant result to reduce circulating levels of CRP, hs-CRP, and TNF- $\alpha$, promoting the pain relief for the individual.

\section{Recommendations}

Elderly with reported knee pain required to perform knee exercises and implement param ginger twice a week. 
Further research necessary to identify the use of drinking ginger to reduce knee pain in the elderly.

\section{Conflict of Interests}

The authors declare that they have no conflict of interest

\section{ACKNOWLEDGMENT}

The author appreciates research participants and all contributors to this study.

\section{REFERENCES}

Ali, A. M.A., El-Nour, M. E.M. \& Yagi, S.M. (2018). Total phenolic and flavonoid contents and antioxidant activity of ginger (Zingiber officinale Rosc.) rhizome, callus, and callus treated with some elicitors. Journal of Genetic Engineering and Biotechnology, 16(2), pp 677-682.

Alipour, Z., Asadizaker, M., Fayazi, S., Yegane, N., Kochak, M. \& Haghighi Zadeh, M.H. (2017). The effect of ginger on pain and satisfaction of patients with knee osteoarthritis. Jundishapur Journal of Chronic Disease Care, 6(1), pp $1-6$.

Bartels, E.M., Folmer, V.N., Bliddal, H., Altman, R.D., Juhl, C., Tarp, S. \& Christensen, R. (2015). Efficacy and safety of ginger in osteoarthritis patients: a meta-analysis of randomized placebo-controlled trials. Osteoarthritis and Cartilage, 23(1), pp 13-21.

Central Bureau of Statistics Indonesia. (2019). Statistik Penduduk Lanjut Usia 2019. Retrieved from: https://www.bps.go.id/ publication/2019/12/20/ab17e75dbe630e05110ae53b/statistik-penduduk-lanjut-usia2019.html.

Firmansyah, D. \& Suprayitno, E. (2018). Pengaruh Latihan Gerak Sendi Lutut Terhadap Nyeri Sendi Lutut Pada Lansia Yang Mengalami Osteoatritis Di Wilayah Kerja Puskesmas Pengasih 1 Kulon Progo Yogyakarta. Retrieved from: http://digilib.unisayogya.ac.id/4322/1/NASPUB_DEDI\%20FIRMANSYAH_201410201017.pdf.

Fransen, M., McConnell, S., Harmer, A.R., Van der Esch, M., Simic, M. \& Bennell, K. L. (2015). Exercise for osteoarthritis of the knee: a Cochrane systematic review. British Journal of Sports Medicine, 49(24), pp 1554-1557.

Funk, J.L., Frye, J.B., Oyarzo, J.N., Chen, J., Zhang, H. \& Timmermann, B.N. (2016). Anti-inflammatory effects of the essential oils of ginger (Zingiber officinale Roscoe) in experimental rheumatoid arthritis. PharmaNutrition, 4(3), pp.123-131.

Gunathilake, K. \& Rupasinghe, V. (2015). Recent perspectives on the medicinal potential of ginger. Botanics: Targets and Therapy. 5, pp 55-63. doi.org/10.2147/BTAT.S68099.

Lee, T.Y., Lee, K.C., Chen, S.Y. \& Chang, H.H. (2009). 6-Gingerol inhibits ROS and iNOS through the suppression of PKC- $\alpha$ and NF- $\kappa$ B pathways in lipopolysaccharide-stimulated mouse macrophages. Biochemical and biophysical research communications, 382(1), pp 134-139.

Manasa, D., Srinivas, P. \& Sowbhagya, H.B. (2013). Enzyme-assisted extraction of bioactive compounds from ginger (Zingiber officinale Roscoe). Food Chemistry, 139(1-4), pp 509-514.

Marlina, T.T. (2015). Efektivitas latihan lutut terhadap penurunan intensitas nyeri pasien osteoarthritis lutut di yogyakarta. Journal Keperawatan Sriwijaya, 2(1), pp 44-56.

Marlina, T. T., Lucilla, S. \& Aima, H. (2019). The effectiveness of hip and knee strengthening on reducing pain intensity among elderly with osteoarthritis. KnE Life Sciences, pp 600-608.

Morvaridzadeh, M., Fazelian, S., Agah, S., Khazdouz, M., Rahimlou, M., Agh, F. \& Heshmati, J. (2020). Effect of ginger (Zingiber officinale) on inflammatory markers: A systematic review and meta-analysis of randomized controlled trials. Cytokine, 135, pp 155224.

Naderi, Z., Mozaffari-Khosravi, H., Dehghan, A., Nadjarzadeh, A. \& Huseini, H.F. (2016). Effect of ginger powder 
supplementation on nitric oxide and C-reactive protein in elderly knee osteoarthritis patients: A 12-week doubleblind randomized placebo-controlled clinical trial. Journal of Traditional and Complementary Medicine, 6(3), pp 199-203. DOI: 10.1016/j.jtcme.2014.12.007.

Permenkes, R.I. (2015). Penyelenggaraan Pelayanan Kesehatan Lanjut Usia Di Pusat Kesehatan Masyarakat. Kementrian Kesehatan Indonesia, pp. 1-140.

Pusat Data dan Informasi Kementrian Kesehatan RI. (2014). Situasi Dan Analisis Lanjut Usia. https://pusdatin. kemkes.go.id/download.php?file=download/pusdatin/infodatin/infodatin-lansia.pdf.

Ramadan, G., Al-Kahtani, M.A. \& El-Sayed, W.M. 2011. Anti-inflammatory and anti-oxidant properties of Curcuma longa (turmeric) versus Zingiber officinale (ginger) rhizomes in rat adjuvant-induced arthritis. Inflammation, 34(4), pp.291-301.

Riskesdas. (2013). Badan Penelitian Dan Pengembangan Kesehatan Kementerian Kesehatan RI Tahun 2013. Retrieved from: http://www.depkes.go.id/resources/download/general/Hasil\%20Riskesdas \%202013.pdf.

Riskesdas. (2018). Badan Penelitian Dan Pengembangan Kesehatan Kementerian Kesehatan Ri Tahun 2018. Retrieved from: http://www.depkes.go.id/resources/download/info-terkini/hasil-riskesdas-2018.pdf.

Rondanelli, M., Riva, A., Allegrini, P., Faliva, M.A., Naso, M., Peroni, G., Nichetti, M., Gasparri, C., Spadaccini, D., Iannello, G. and Infantino, V., 2020. The Use of a New Food-Grade Lecithin Formulation of Highly Standardized Ginger (Zingiber officinale) and Acmella oleracea Extracts for the Treatment of Pain and Inflammation in a Group of Subjects with Moderate Knee Osteoarthritis. Journal of Pain Research, 13, p 761-770.

Rondanelli, M., Fossari, F., Vecchio, V., Gasparri, C., Peroni, G., Spadaccini, D., Riva, A., Petrangolini, G., Iannello, G., Nichetti, M. \& Infantino, V. (2020). Clinical trials on pain lowering effect of ginger: A narrative review. Phytotherapy Research, 34(11), pp.2843-2856.

Semwal, R.B., Semwal, D.K., Combrinck, S. \& Viljoen, A.M. (2015). Gingerols and shogaols: Important nutraceutical principles from ginger. Phytochemistry, 117, pp 554-568.

The World Bank. Life expectancy at birth, total (years) - Indonesia. Life expectancy at birth, total (years) - Indonesia | Data (worldbank.org).

Wang, X., Zheng, Z., Guo, X., Yuan, J. \& Zheng, C. (2011). Preparative separation of gingerols from Zingiber officinale by high-speed counter-current chromatography using stepwise elution. Food Chemistry, 125(4), pp 1476-1480. 